\title{
Differences in Expulsion on Post-placenta Intrauterine Contraceptive Device between Mother with Vaginal and Cesarean Delivery
}

\author{
Atika Zahria Arisanti, ${ }^{1,2}$ Tono Djuwantono, ${ }^{3}$ Sri Endah Rahayuningsih ${ }^{4}$ \\ ${ }^{1}$ Midwifery Master Study Program, Faculty of Medicine, Universitas Padjadjaran, Bandung, Indonesia, \\ ${ }^{2}$ Department of Midwifery, Faculty of Medicine, Universitas Islam Sultan Agung, Semarang, Indonesia, \\ ${ }^{3}$ Department of Obstetrics and Gynecology, Faculty of Medicine, Universitas Padjadjaran/Dr. Hasan Sadikin \\ General Hospital, Bandung, Indonesia, ${ }^{4}$ Department of Child Health, Faculty of Medicine, \\ Universitas Padjadjaran/Dr. Hasan Sadikin General Hospital, Bandung, Indonesia
}

\begin{abstract}
Intrauterine device (IUD) is a long term, highly effective, and reversible contraception method. In Indonesia, the number of IUD acceptors is still lower than other methods. An effort to improve the long term contraception is using post-placental IUD that can be a choice for postpartum mother who has limited access to another contraception service. The purpose of this study was to compare the incidence of expulsion in post-placental IUD insertion between mother with vaginal delivery and cesarean delivery. This study design was a comparative cross-sectional method with a consecutive sampling technique conducted at Dr. Hasan Sadikin General Hospital Bandung and Dr. Kariadi General Hospital Semarang from November 2017 to February 2018. Subjects were postpartum mothers who received post-placental IUD insertion at vaginal delivery and cesarean delivery. Samples were 96 women, consisting of 48 women with IUD insertion in vaginal delivery and 48 women with IUD insertion in cesarean delivery. Data obtained from interviews and transvaginal ultrasonography examination. The result showed there was a difference in expulsions incidence between IUD's insertion among vaginal delivery compared to cesarean delivery $(p=0.041)$. It concluded that expulsion's to post-placental IUD insertion is higher in vaginal delivery compared to cesarean delivery.
\end{abstract}

Key words: Cesarean delivery, expulsion, post-placental IUD, vaginal delivery

\section{Perbedaan Kejadian Ekspulsi pada Pemasangan Alat Kontrasepsi dalam Rahim Pascaplasenta antara Ibu dengan Persalinan per Vaginam dan Persalinan Sectio Caesarea}

\begin{abstract}
Abstrak
Alat kontrasepsi dalam rahim (AKDR) merupakan kontrasepsi jangka panjang, efektif dan reversibel. Di Indonesia, jumlah akseptor AKDR masih lebih rendah daripada metode lainnya. Salah satu upaya untuk meningkatkan penggunaan kontrasepsi jangka panjang, yaitu dengan AKDR pascaplasenta yang dapat menjadi alternatif bagi ibu pascasalin yang mempunyai akses terbatas untuk mendapatkan pelayanan kontrasepsi. Penelitian ini bertujuan membandingkan kejadian ekspulsi pada pemasangan AKDR pascaplasenta antara ibu dengan persalinan pervaginam dan persalinan sectio caesarea. Desain penelitian ini adalah cross-sectional komparatif dengan teknik pengambilan sampel consecutive yang dilaksanakan di RSUP Dr. Hasan Sadikin Bandung dan RSUP Dr. Kariadi Semarang dari bulan November 2017 hingga Februari 2018. Subjek penelitian adalah ibu pascasalin yang mendapatkan insersi AKDR pascaplasenta pada persalinan per vaginam dan persalinan sesar. Jumlah sampel 96 ibu, terdiri atas 48 ibu yang bersalin per vaginam dan 48 ibu yang bersalin sesar. Data didapatkan melalui wawancara dan pemeriksaan ultrasonografi transvaginal. Hasil penelitian menunjukkan terdapat perbedaan kejadian ekspulsi pada pemasangan AKDR antara ibu dengan persalinan per vaginam dan persalinan sectio caesarea $(\mathrm{p}=0,041)$. Simpulan, kejadian ekspulsi pada pemasangan AKDR pascaplasenta lebih tinggi pada ibu dengan persalinan per vaginam dibanding dengan persalinan sectio caesarea.
\end{abstract}

Kata kunci: AKDR pascaplasenta, ekspulsi, persalinan per vaginam, persalinan sectio caesarea

Received: 20 April 2018; Revised: 8 April 2020; Accepted: 25 April 2020; Published: 30 April 2020

Correspondence: Atika Zahria Arisanti, S.S.T., M.Keb. Diploma 3 Midwifery Study Program, Faculty of Medicine, Universitas Islam Sultan Agung. Jln. Raya Kaligawe km 4, Semarang 50112, Central Java, Indonesia. E-mail: ika.zahria@gmail.com 


\section{Introduction}

The use of contraceptives in Indonesia is still dominated by modern contraceptive methods that are short-term and contain a hormone that generally has a low levels continuation rate compared to long-term contraceptive methods. ${ }^{1,2}$ The use of short-term contraceptives such as injections and pills is $40 \%$, while the longterm contraceptive (vasectomy, tubectomy, intrauterine device, and implant) is $23.5 \%$. The lower acceptance of long term contraception by women in Indonesia caused by some factors. These are the factor image of contraception, lack of information factor about benefits, effectiveness, and side effect of long term contraception. ${ }^{1}$

The indicators of successful family planning are contraceptive prevalence rate (CPR) and unmet need. The percentage of unmet needs in Indonesia increased by $8.5 \%$. An increase in unmet need indicates a decrease in CPR, which means that contraceptive services and access to fertile-age couples to contraceptives are not enough. ${ }^{1}$

The main target of the family planning program is in the unmet need group and the postpartum mother, both in normal and cesarean delivery. One of the efforts to increase the coverage of family planning participation and to improve the quality of postpartum mother's health is to seek family planning after delivery. Postpartum family planning is the use of contraceptive methods immediately after delivery to 6 weeks (42 days). ${ }^{2,3}$

Population and family planning programs offer a range of relatively safe and effective contraceptive methods of postpartum delivery, one of which is the post-placebo intrauterine device (IUD). Following the Indonesian Health Technology Assessment issued by the Ministry of Health on family planning during the breastfeeding period, one of the efforts in increasing the use of long-term contraceptives aimed at postpartum mothers by using postplacebo IUD in regulating gestational distances without affecting the production of breast milk (air susu ibu/ASI). ${ }^{1,4}$

The results of the Indonesian Health Technology Assessment Indonesia study showed several levels of expulsion at the time of insertion. For insertion on premature post-placenta (10 minutes after placenta born) are 9.5-12.5\%, immediately insertion after delivery (more than 10 minutes to 48 hours postpartum) are $25-37 \%$, and insertion during the postpartum interval
(>4 weeks postpartum) are 3-13\%. Expulsion generally occurs during the first three months post-insertion and at most in the first 4-6 weeks. Expulsion is the exclusion of an IUD from within the uterus that can occur partly or entirely. ${ }^{1,4}$

Post-placental IUD insertion after vaginal delivery has an expulsion rate of up to $24 \%$. However, observational studies show that the rate of expulsion in post-placental insertion after the cesarean section is much lower. In theory, it is because placement on the fundus is more likely to minimize the failure and likelihood that the cervix is less fully dilate.., 6

The purpose of this study was to compare the incidence of expulsion in post-placental IUD insertion between mother with vaginal delivery and cesarean delivery.

\section{Methods}

The design of this study was a comparative cross-sectional. This study conducted at Dr. Hasan Sadikin General Hospital Bandung and Dr. Kariadi General Hospital Semarang from November 2017 to February 2018. Samples selected by consecutive sampling technique, which meets the selection criteria. The inclusion criteria in this study were mothers who gave vaginal delivery and cesarean delivery. They received post-placebo IUD insertion with the duration of use at least 4-6 weeks post-insertion, using a CuT 380 A IUD. The subject of the study was the mother who gets insertion post-placenta IUD, both vaginal delivery and cesarean delivery. The subjects used have met the inclusion and exclusion criteria with the sample number of 96 respondents.

The data used in this study are primary and secondary. Primary data were obtained from respondents through interview technique and transvaginal ultrasound examination to determine the location and position of IUD related to expulsion occurrence. In contrast, secondary data obtained from maternity register in the hospital.

The selection of study subjects was conducted by looking at the existing maternity registers in each study site that met the inclusion and exclusion criteria. After obtaining the data through the maternity registers, the researcher contacted each respondent by phone and mail to confirm whether the respondent was willing to include in the study. Respondents selected and willing to undergo the transvaginal ultrasound to observe 
the location and position of the IUD recruited for the study. The transvaginal ultrasound examination aims to determine the occurrence of expulsion on post-placebo IUD insertion in the vaginal delivery and cesarean delivery mother. Transvaginal ultrasound examination performed by obstetric and gynecologist specialist on duty at the study site.

The processing of the data collected analyzed using SPSS version 17 applications. The statistical test used in this study is the chi-square test $(\times 2)$ with a 95\% confidence level and 0.05 significance level. As an alternative test, Fisher's exact test used if the chi-square test is not appropriate.

This study approved by the Health Research Ethics Committee of Faculty of Medicine of Universitas Padjadjaran Bandung with the letter number: 1228/UN6.C.10/PN/2017.

\section{Results}

Table 1 shows the frequency distribution of respondent characteristics on the insertion of a post-placental intrauterine contraceptive device between mothers with vaginal delivery and cesarean delivery. Age characteristics had p value $=0.174$ and parity $\mathrm{p}$ value $=0.343$.

Table 2 shows that there are differences in the occurrence of expulsion on the insertion of a post-placenta intrauterine contraceptive device between mothers with vaginal delivery and cesarean delivery with $\mathrm{p}$ value $=0.041$. All respondents who experienced the occurrence of expulsion in the vaginal delivery group of 4 (8\%) respondents.

Table 3 shows the relationship between age and parity with expulsion occurrence. The result was the $\mathrm{p}$ value $=0.638$ on variable age and $\mathrm{p}$ value $=0.934$ on variable parity.

\section{Discussion}

The respondent characteristic shows that the majority of respondents aged 20-35 years, 40 respondents in the vaginal delivery group, and 39 respondents in the cesarean delivery group with $p$ value $=0.174$. Based on parity in two groups, it was almost equal between the vaginal delivery group and cesarean delivery with $\mathrm{p}$ value $=0.343$. Based on these results, it can be concluded that

Table 1 The Frequency Distribution of Respondent Characteristic on Two Group

\begin{tabular}{|c|c|c|c|}
\hline \multirow[b]{2}{*}{$\begin{array}{l}\text { Respondent } \\
\text { Characteristic }\end{array}$} & \multicolumn{2}{|c|}{ Groups } & \multirow[b]{2}{*}{ p Value } \\
\hline & $\begin{array}{l}\text { Vaginal Delivery } \\
(n=48)\end{array}$ & $\begin{array}{c}\text { Cesarean Delivery } \\
(n=48)\end{array}$ & \\
\hline \multicolumn{4}{|l|}{ Age (years) } \\
\hline$<20$ & $1(2 \%)$ & $5(11 \%)$ & \multirow{5}{*}{0.174} \\
\hline $20-35$ & $40(83 \%)$ & $39(81 \%)$ & \\
\hline$>35$ & $7(15 \%)$ & $4(8 \%)$ & \\
\hline Mean (SD) & $29.03(6.5)$ & $29.03(6.5)$ & \\
\hline Range & $16-47$ & $16-47$ & \\
\hline \multicolumn{4}{|l|}{ Parity } \\
\hline Primiparous & $13(27 \%)$ & $15(31 \%)$ & \multirow{3}{*}{0.343} \\
\hline Multiparous & $33(69 \%)$ & $33(69 \%)$ & \\
\hline Grand multiparous & $2(4 \%)$ & $\mathrm{O}(\mathrm{O} \%)$ & \\
\hline
\end{tabular}

Note: ${ }^{*}$ Chi-square test

Table 2 The Relationship between the Post-placental IUD on Cesarian Delivery and Vaginal Delivery with Expulsion Occurrence

\begin{tabular}{|c|c|c|c|}
\hline \multirow{2}{*}{ Post-placental IUD Insertion } & \multicolumn{2}{|c|}{ Expulsion Occurrence } & \multirow{2}{*}{ p Value } \\
\hline & Yes $(n=4)$ & No $(n=92)$ & \\
\hline $\begin{array}{l}\text { Vaginal delivery } \\
\text { Cesarean section }\end{array}$ & $\begin{array}{l}4(8 \%) \\
0(0 \%)\end{array}$ & $\begin{array}{c}44(92 \%) \\
48(100 \%)\end{array}$ & 0.041 \\
\hline
\end{tabular}


Table 3 The Relationship between Age and Parity with Expulsion Occurence

\begin{tabular}{lccc}
\hline \multirow{2}{*}{ Age and Parity } & \multicolumn{2}{c}{ Expulsion Occurrence } & \multirow{2}{*}{ p Value $^{*}$} \\
\cline { 2 - 3 } & Yes (n=4) & No (n=92) & \\
\hline Age (year) & 0 & 6 & 0.638 \\
$<20$ & 4 & 75 & \\
$20-35$ & 0 & 11 & 0.934 \\
$>35$ & & & \\
Parity & 1 & 63 & \\
Primiparous & 3 & 2 & \\
Multiparous & 0 & 03 & \\
Grand multiparous & 0 & & \\
\hline
\end{tabular}

Note: ${ }^{*}$ Chi-square test

age and parity are homogeneous and feasible to compare.7,8

From the statistics results by using Fisher exact test, obtained $p$ value $=0.041$, it means that there are differences in the expulsion occurrence of post-placenta IUD insertion between mother with vaginal delivery and cesarean delivery. A percentage of vaginal deliveries with an expulsion occurrence is higher, found in 4 (8\%) respondents than the cesarean delivery, in which all respondents had no expulsion. The results mean that the post-placenta IUD insertion in vaginal delivery has a higher occurrence of expulsion than in cesarean delivery with a difference in age and parity..$^{7-8}$ Expulsion occurrence is higher on vaginal delivery than cesarean delivery because there is maximal dilatation cervix than cesarean..$^{10,11}$

Post-placental IUD expulsion in vaginal delivery occurs due to the cervical dilatation in the lower segment of the uterus as well as the development of a thin lower uterine segment. ${ }^{12}$ It is estimated to be the cause of partial expulsion..$^{13-15}$ While the cesarean delivery that is not planned before and conducted while entering the active period has a high risk as well. ${ }^{16}$ In this study, all cesarean delivery is upon indication and planned so that the risk of expulsion minimized because it does not pass through an active phase of delivery that the cervix is not fully dilated. Postplacental IUD insertion after vaginal delivery has been shown to have an expulsion rate of up to $24 \%$. However, observational studies show that the rate of expulsion in post-placental insertion after cesarean is much lower. Theoretically, because placement on the fundus is more likely to minimize the failure and likelihood, the cervix is less fully dilate..$^{15}$

The results of this study found that all respondents in a vaginal delivery experienced partial expulsion. Expulsion is the exclusion of an IUD from within the uterus that can occur partly or entirely. Partial expulsion is a condition in which the IUD stem located below the internal os and cervical canal. In contrast, total expulsion is a condition in which the IUD stems out from inside the uterus through the cervix e.g., in the vagina. ${ }^{15,17,18}$

In this study, transvaginal ultrasound to evaluate the expulsion confirmed by obstetric and gynecologist specialists. Observed on two respondents with the location of the IUD stem is under internal os, and on two other respondents, the IUD stem located in the cervical canal. The expulsion rate of the IUD via vaginal insertion was not only the one helped by midwives but also found in mothers helped by medical doctors too. The results of interviews showed that some respondents complained of pain during sex, experiencing spots (spotting), and feel the discomfort because the IUD strings are too long, which interfering with sexual activity.

The risk factors that may lead to an IUD expulsion include age, parity, insertion time (cervix dilatation), previous expulsion history, type and size of the IUD, insertion techniques, and the attending medical personnel. ${ }^{18-21}$

Another factor is age and parity. In this study, the majority of respondents who experienced the incidence of expulsion mostly aged 20-35 years with parity of 2-4 (multipara). There was no significant association with age and parity of the incidence of expulsion. The result of this study supported by the study of Sucak et al. ${ }^{7}$ that mentioned there is no significant correlation between the age of respondents with the incidence of IUD expulsion, both from normal labor and cesarean ones. Although there is no statistically 
significant relationship, it showed the percentage of incidence of expulsion higher at $<35$ years old more $(5 \%)$ than age $>35$ years (none). ${ }^{22-24}$

In this study, there was no relationship between parity and expulsion occurrence. This study wasn't differenced with the study from Garishah ${ }^{25}$ that there was a significant relationship between parity and the incidence of expulsion in post placental IUD insertion, with a greater percentage of multiparous (66.3\%), primipara (33.7\%), and grand multipara (25.9\%). Parity is a risk factor for expulsion, the occurrence of expulsion increases in multiparous with vaginal delivery due to cervical dilatation in the lowest uterine segment. Unplanned section cesarea deliveries also have a high risk but the effect of cervical dilatation and expulsion is still not enough evidence. ${ }^{7}$

\section{Conclusion}

There was a difference in expulsion occurrence on post-placental intrauterine device contraceptive insertion between mother with vaginal delivery and cesarean delivery. The expulsion occurrence of vaginal delivery is higher than cesarean delivery.

\section{Conflict of Interest}

There is no conflict of interest at all authors.

\section{References}

1. Direktorat Jenderal Bina Gizi dan Kesehatan Ibu dan Anak, Kementerian Kesehatan Republik Indonesia. Pedoman pelayanan keluarga berencana pasca persalinan di fasilitas kesehatan [Internet]. Jakarta: Kementerian Kesehatan Republik Indonesia; 2014 [cited 2018 June 20]. Available from: http://kesga.kemkes.go.id/images/ pedoman/Buku\%2oPedoman\%20KB\%20 Pasca\%2oPersalinan.pdf.

2. United Nations, Department of Economic and Social Affairs, Population Division. World contraceptive use 2018 [Internet]. New York: United Nations; 2018 [cited 2018 July 22]. Available from: https://www. un.org/en/development/desa/population/ publications/dataset/contraception/ wcu2018/UNPD_WCU2018_Country_ Data_Survey-Based.xlsx..

3. Pasha O, Goudar SS, Patel A, Garces A, Esamai
F, Chomba E, et al. Postpartum contraceptive use and unmet need for family planning in five low-income countries. Reprod Health. 2015;12(Suppl 2):S11.

4. Pusat Data dan Informasi, Kementerian Kesehatan Republik Indonesia. Situasi dan analisis keluarga berencana [Internet]. 2014 June 29 [cited 2018 July 22]. Available from: https://pusdatin.kemkes.go.id/resources/ download/pusdatin/infodatin/infodatin-kb. pdf.

5. Lester F, Kakaire O, Byamugisha J, Averbach $\mathrm{S}$, Fortin J, Maurer R, et al. Intracesarean of the copper T380A versus 6 week postcesarean: a randomized clinical trial. Contraception. 2015;91(3):198-203.

6. Chhari A, Zutshi V, Sharma R, BatraS. Comparison of post placental IUD with interval IUD. Int J Reprod Contracept Obstet Gynecol. 2015;4(4):1090-3.

7. Sucak A, Ozcan S, Çelen Ş, Çağlar T, Göksu G, Danışman N. Immediate postplacental insertion of a copper intrauterine device: a pilot study to evaluate expulsion rate by mode of delivery. BMC Pregnancy Childbirth. 2015;15:202.

8. American College of Obstetricians and Gynecologists' Committee on Gynecologic Practice; Long-Acting Reversible Contraceptive Expert Work Group. Committee Opinion No 672: clinical challenge of long-acting reversible contraceptive methods. Obstet Gynecol. 2016;128(3):e6977 .

9. Letti Muller AL, Lopes Ramos JG, Martins-Costa SH, Palma Dias RS, Valerio EG, Hammes LS, et al. Transvaginal ultrasonographic assessment of expulsion rate of intrauterine device inserted in the immediate postpartum period: a pilot study. Contraception. 2005;72(3):192-5.

10. Affandi B, Adriaansz G, Gunardi ER, Koeno H. Buku panduan praktis pelayanan kontrasepsi. $3^{\text {rd }}$ Edition. $4^{\text {th }}$ Printing. Jakarta: PT Bina Pustaka Sarwono Prawirohardjo; 2014.

11. Cunningham FG, Leveno KJ, Bloom SL, Hauth JC, Rouse DJ, Spong CY. Obstetri Williams. $23^{\text {rd }}$ Edition. Volume 1. Jakarta: EGC; 2012.

12. Kapp N, Curtis KM. Intrauterine device insertion during the postpartum period: a systematic review. Contraception. 2009;80(4):327-36. 
13. Jatlaoui TC, Marcus M, Jamieson DJ, Goedken P, Cwiak C. Postplacental intrauterine device insertion at a teaching hospital. Contraception. 2014;89(6):528-33.

14. Rahaman M, Sood AK, Srivasta AK. Evaluation of spontaneous expulsion after immediate postpartum intrauterine contraceptive devices (PPIUCDs) insertion. IOSR-JDMS. 2017;16(5):60-3.

15. Putri FH. Pengaruh penjahitan AKDR terhadap insiden ekspulsi pada pemasangan AKDR CuT 380A pascasalin seksio sesaria [thesis]. Jakarta: Universitas Indonesia; 2014 [cited 2018 March 30]. Available from: http://lib.ui.ac.id/file?file=digital/20162/20391336-SP-Farani\%2oHarida\%20 Putri.pdf.

16. Hubacher D, Reyes V, Lillo S, Pierre-Louis B, Zepeda A, Chen PL, et al. Preventing copper intrauterine device removals due to side effects among first-time users: randomized trial to study the effect of prophylactic ibuprofen. Hum Reprod. 2006;21(6):146772.

17. Goldthwaite LM, Sheeder J, Hyer J, Tocce K, Teal SB. Postplacental intrauterine device expulsion by 12 weeks: a prospective cohort study. Am J Obstet Gynecol. 2017;217(6):674. e1-8.

18. Fernandes JHA, Lippi U. A clinical and ultrasound study on the use of postplacental intrauterine device. Einstein (São Paulo). 2004;2(2):110-4.

19. Nowitzki KM, Hoimes ML, Chen B, Zheng
LZ, Kim YH. Ultrasonography of intrauterine devices. Ultrasonography. 2015;34(3):18394.

20. Lindheim SR, Uhler ML. Pelvic ultrasonography and sonohysterography. In: Falcone T, Hurd WW, editors. Clinical reproductive medicine and surgery. Philadelphia: Mosby Elsevier; 2007. p. 44160.

21. Evans A. Postpartum contraception. Womens Health Med. 2005;2(5):23-6.

22. The ACQUIRE Project. The postpartum intrauterine device: a training course for service providers: participant handbook. New York: EngenderHealth/The ACQUIRE Project; 2008.

23. Eroğlu K, Akkuzu G, Vural G, Dilbaz B, Akin A, Taşkin L, et al. Comparison of efficacy and complications of IUD insertion in immediate postplacental/early postpartum period with interval period: 1 year follow-up. Contraception. 2006;74(5):376-81.

24. Fritz MA, Speroff L. Clinical gynecologic endocrinology and infertility. 8th Edition. Philadelphia: Wolters Kluwer; 2011.

25. Garishah GH. Hubungan antara paritas terhadap kejadian ekspulsi IUD pada akseptor IUD post placental delivery pada persalinan spontan di Kota Magelang [undergraduate thesis]. Yogyakarta: Universitas Muhammadiyah Yogyakarta; 2013 [cited 2018 October 19]. Available from: http://repository.umy.ac.id/ handle/123456789/7117. 